\title{
DOES FEEDBACK PLAY A ROLE DURING THE CONSTRUCTION OF INTERNAL CUSTOMERS' PSYCHOLOGICAL CAPITAL?
}

\author{
*Esra DEMIRBAS ${ }^{1}$ (Orcid ID: 0000-0001-5717-734X) \\ *Hande OZEK (Orcid No: 0000-0002-1374-8398) \\ Istanbul Yeni Yüzyıl University
}

\begin{abstract}
This paper examines the role of feedback on internal customers' psychological capital. The purposive sampling method is used for this study. 307 employees are reached during the survey. The criteria of respondents were to work in medium and large-sized companies as we assumed that in small-sized companies' employees are working more one-to-one with their managers and so they have a higher chance of receiving positive/negative feedback. Receiving feedback or perceiving feedback, either good or not, may have an impact on the behaviors of employees. In the expectation that employees demonstrate positive organizational behavior in the workplace, we aimed to point out, receiving feedback may help to improve internal customers' self-efficacy, hope, optimism, and resiliency, the four subdimension of psychological capital. We wanted to add value to the literature by pointing out what role it plays in feedback on the psychological capital of internal customers. Moreover, we aimed to clarify the moderating effect of total seniority in the relationship of feedback and the facet of psychological capital.
\end{abstract}

Keywords: Internal customers, Feedback, Psychological capital (self-efficacy, hope, optimism, resiliency).

\section{INTRODUCTION}

Internal customers are the key resources to produce goods and serve to the end customer and, thereby, they play a vital role in creating customer satisfaction (Mohr-Jackson, 1991). The internal customers of an organization are its employees (Gummesson, 1987; Bowen and Schneider, 1988; George, 1990). They are the key components to ensure the sustainable competitive advantage of the organization. The feedback given to the internal customers is critical for effective performance management. Positive states of selfefficacy, hope, optimism, and resiliency, separately and when the four were combined into a core construct of psychological capital, significantly correlated with the performance of the internal customers. The purpose of this paper is to reveal the relation of positive and negative feedback on the psychological capital of internal customers and to search deeply the relations between feedback and the subdimensions of the psychological capital.

Although in the last decades there are several studies on psychological capital, in international literature the number of studies directly studied the relation between feedback and psychological capital is few. In addition to this, in the literature review, it is not encountered any study in Turkey directly studying the feedback and the psychological capital within its subdimensions. So, we wanted to add value to the literature, filling the gap by making an analysis and finding out the effects of positive and negative feedback on the psychological capital and its subdimensions in Istanbul, Turkey. We also aimed to add value to the practice, revealing the importance of positive and negative feedback on subdimensions of PsyCap, thus, create more positive organizational behavior in the organization.

In this study, we wanted to discuss PsyCap from a different perspective which we believe needs to be analyzed deeply. We think that self-efficacy, hope, optimism, and resiliency are important facts on positive behavior in the workplace. All these factors may be affected by others' comments on one's performance. In the literature, several theories emphasize the importance and positive effects of feedback for employees' task performance. So far, investigations about feedback, are mostly focused on its effects on task performance (e.g., Locke \& Latham, 2002) and far less on the impact on other elements of overall performance. With this study, we wanted to reveal the relation between positive/negative feedback and selfefficacy, hope, optimism, resiliency to show that receiving feedback may create a higher level of

${ }^{1}$ Corresponding Author 
psychological capital in internal customers. Thereby, this may lead to more positive behavior and a higher level of performance.

\section{LITERATURE REVIEW}

\section{Feedback}

Feedback is information about the accuracy and appropriateness of past behaviors, in more detail, decisions or operations and activities (Ilgen, Fisher and Taylor, 1979). Many previous studies analyzed the effects of managerial feedback on employees' job performance. Feedback, in this regard, is defined as providing information to the employee by his/her supervisor about his/her task performance (Kluger and DeNisi, 1996: 255).

Based on previous studies, sources of feedback may be identified in three categories: (a) organizational and supervisory communications, (b) individuals not in a formal hierarchical relationship (usually co-workers but conceivably others outside the organization, such as clients), and from (c) the process of performing the task (task or self-feedback) (Harold and Parsoons, 1985). The important aspect of a feedback message is its sign. Feedback can be positive or negative.

Negative feedback refers to obtaining information about poor job performance and negative work behaviors (Ashford and Tsui, 1991; Moss, Valenzi, and Taggart, 2003). Previous studies have stated that an employee receiving negative feedback may not act rationally, arguing that employees believe that negative feedback will damage their self-confidence and highlight their weaknesses about their work performance (Ashford, Blatt, and VandeWalle, 2003; Trope and Neter, 1994).

Thorndike's theory of influence (1913) conceptualizes negative feedback as punishment that prevents some behaviors, whereas positive feedback provides the repetition of the desired behavior. Following studies have supported Thorndike's theory of influence and found that performance improvements follow positive feedback. Researchers often explain these results by referring to positive reinforcement for the desired behavior pattern. Especially when the employee believes that his/her self-efficacy increases because of the feedback, and when the feedback is combined with the rewards, the employee's willingness to perform increases. (Bandura,1986; Phillips, Hollenbeck, and Ilgen,1996).

Successful leaders give constant feedback on their subordinates' performance (e.g., Larson, 1989). Performance appraisal systems can be seen as a form of giving feedback to employees about their performance. (Pearce \& Porter, 1986). Here, we argue that employees' affective reactions to feedback also influence such broader conceptions of job performance that include positive behavior in the workplace which we expect to be affected by internal customers' self-efficacy, hope, optimism, and resiliency.

\section{Psychological Capital}

The positive psychological state of development of an employee is called Psychological capital (PsyCap) and is characterized by four subdimension. The first is self-efficacy, the employee's self-confidence to put in the necessary effort to succeed at challenging tasks. The second subdimension is optimism, having a positive view about succeeding today and in the future. The third subdimension is hope. It is persevering toward goals and to be able to succeed, when necessary, changing paths to goals. The last subdimension is resiliency. It is dealing with problems without surrendering until resolving the case (Luthans et al., 2007).

The holistic mental state that will consist of individual benefits to be obtained because of gaining experience-based rewards such as knowledge, skills, and talent development is also called psychological capital. The importance of psychological capital is not only because it is open to development, but it is also related to performance. Luthans et al. (2010) remark that short-term training may develop psychological capital and may affect positively employee's performance (Luthans, Avey, Avolio and Peterson, 2010).

In this respect, we assumed that receiving feedback would have an important role on internal customers' psychological capital. Thus, our first hypotheses are:

\section{H1: Positive feedback affects internal customers' psychological capital.}

\section{H2: Negative feedback has impact on psychological capital of internal customers.}

Studies have shown that when employees' job performance is below the expected standard, but they have a positive self-concept they receive negative feedback rationally. They tend to increase their efforts in line 
with the feedback, try to match their performance to the standards. Conversely, people who have a negative self-concept in response to negative feedback tend to either lower their performance or completely withdraw from the task (Bandura and Cervone, 1983; Brockner, 1988; Weiss and Sherman, 1973). Regarding this result, we assumed that all subdimensions of psychological capital could be related to feedback.

In the presence of low performance and negative feedback, individuals high on self-esteem, self-efficacy, and internal locus of control, tend to increase their effort, they should be better performers than those individuals with low self-esteem, self-efficacy, or externals who tend to lower their standards or withdraw from the task. (Youssef, C. M., and Luthans, F. (2007).

Therefore, we assumed:

\section{H1a: Positive feedback affects self-efficacy.}

\section{H2a: Negative feedback affects self-efficacy.}

The concept of hope is based on Snyder's (2000) theory of hope and is defined as "a positive motivational state that is based on an interactively derived sense of successful (1) agency (goal-directed energy) and (2) pathways (planning to meet goals)" (Snyder, Irving, and Anderson, 1991: 287). Hope is applicable and linked with the performance of workers in various fields. (Adams et al., 2002; Curry, Snyder, Cook, Ruby, and Rehm, 1997; Luthans, Avolio, Walumbwa and Li, 2005; Luthans and Jensen, 2002; Luthans, Van Wyk and Walumbwa, 2004; Peterson and Luthans, 2003; Snyder, 1995b; Youssef and Luthans, 2006). Regarding this, we assumed that feedback could play an important role in employees' sense of success and in their plans to meet goals.

\section{H1b: Positive feedback raises hope.}

\section{H2b: Negative feedback raises hope.}

Optimism is an approach that bases positive events on personal, continuous, and common reasons, whereas negative events are on external, temporary, and situation reasons. (Seligman, 1998). In another definition, optimistic people describe bad events as temporary and good ones as permanent situations whereas pessimists tend to attribute bad events as permanent and general, and good events as temporary (Luthans et al., 2004). Optimism has a recognized performance impact in work settings (Luthans et al., 2005; Seligman, 1998) and so meeting the positive organizational behavior. The attribution mechanisms of optimism, especially for negative events and failures, are not limited to the self but also include external causes such as other people or situational factors (Seligman, 1998). Therefore, we assumed that feedback can be a factor in the approach of optimism.

\section{H1c: Positive feedback has a positive impact on optimism.}

\section{H2c: Negative feedback has a negative impact on optimism.}

Resilience, which is another dimension of psychological capital, is the ability to recover from a difficult situation, uncertainty, conflict, or even after serious negative changes (Hobfoll, Stevens and Zalta, 2015; Luthans et al., 2004, Luthans et al. (2007). Luthans (2002a:702) defines resilience as "the developable capacity to rebound or bounce back from adversity, conflict, and failure or even positive events, progress, and increased responsibility". Resilience allows for not only reactive recovery but also proactive learning and growth through conquering challenges. So, we assumed feedback can play a role in resilience, and thus our hypotheses are:

\section{H1d: Positive feedback affects resilience.}

\section{H2d: Negative feedback affects resilience.}

In our research, we also examined thoroughly demographical factors such as gender, education, job tenure. Based on our previous study, we especially point out that job tenure, total seniority of work life span, may have a moderating effect on feedback and PsyCap. In the literature review, in general, we had encountered two different theoretical frameworks in the studies analyzing job tenure. The first one is the Human Capital Theory. According to Ng and Feldman 2010, the employee with a higher tenure would have a higher level of knowledge and skills. Second, according to the Attraction-Selection-Attrition Theory (Schneider, Goldstein, and Smith 1995), employees with better person-organization fit are those who are through self- 
selection remain in the organization and generally, are highly tenured. Based on these theories we thought that feedback may play an important role in the work life span either to gain task-related knowledge and skills or to have a better person-organization fit. In addition to this, the results of our previous study (Demirbaş and Özek,2020) showed that job tenure is affecting the several subdimensions of PsyCap such as employees who have tenure of more than nine years are more resilient.

In this study, we wanted to reveal the moderating effect total on feedback and PsyCap's subdimensions. So, we assumed that.

H3: Total seniority moderates the effect of feedback on the dimensions of PsyCap

H3a: The effect of positive feedback on self-efficacy is moderated by total seniority.

H3b: Total seniority moderates the impact of negative feedback on self-efficacy.

H3c: Total seniority moderates the influence of positive feedback in optimism.

H3d: The impact of negative feedback on hope is moderated by total seniority.

\section{RESEARCH METHOD}

\section{Data collection method and sampling}

Our descriptive research was designed to find out how feedback affects internal customers' psychological capital. To assess this relationship, we created an online structured questionnaire to gather the preliminary data. The online questionnaire was based on the survey results of a pretest that was carried out with fortyfour people. The results of the pretest seemed relevant to continue.

The data was obtained utilizing a convenience sampling technique as a non-probabilistic sampling method (Malhotra, 2009). The structured questionnaire is surveyed among 307 attendants. These are the members of the medium and large-size companies that were based in İstanbul and with those, the researchers had already been in contact. The survey was taking place between June -December 2019. 212 responses were received at the end of September 2019. The remaining 95 responses were received within October and November 2019. Since no more contribution was occurred by December 2019, the survey was terminated.

\section{Measures}

The structured questionnaire is composed of Sujan's, Weitz's, and Kumar's (1994:47) positive and negative feedback scales including 22 statements consisting of 16 original and 6 reverse checking statements that are measured with "Likert-type 5-point scales ranging from 1 (strongly disagree) to 5 (strongly agree) and of Luthans, Youssef and Avolio's (2007) PsyCap scale that was translated into Turkish by Çetin and Basım (2012) including 20 statements, was used in the research. In terms of reliability, the Cronbach Alpha value of positive feedback is 0.942 and 0.885 for the positive one, which is close to the coefficient alphas of Sujan, Wietz, and Kumar (1995) reported coefficient alpha of 0.94 for positive feedback and of 0.89 for a negative one. The reliability of positive Luthans' (2007) original scale includes 24 statements as six items for each facet (optimism, hope, self-efficacy and resilience) The Cronbach alphas for the four surveyed samples of Luthans' (2007:555), were as follows: Hope $(0.72,0.75,0.80,0.76)$; resilience $0(.71,0.71,0.66$, $0.72)$; self-efficacy $(0.75,0.84,0.85,0.75)$; optimism $(0.74,0.69,0.76,0.79)$. The scale results present generally acceptable levels of internal consistency and also overall PsyCap results demonstrate strong reliability in all four samples. Meanwhile, Çetin's and Basım's (2012:137) adopted Luthans' PsyCap study is composed of 4 statements of optimism, 5 statements of hope, 6 statements of self-efficacy, and 5 statements of resilience, totally 20 statements that are measured with "Likert-type 5-point scales ranging from 1 (strongly disagree) to 5 (strongly agree). The Cronbach Alphas of this adopted scale (Çetin and Basim, 2012:129) are;0.85 for self-efficacy, 0.81 for hope, 0,67 for optimism, and finally0.68 for resilience.

During the back translation of PsyCap statements into English, the scales of Scheiner and Carver's (1985:225) optimism, Wagnild and Young's (1993) resilience, Snyder's et al. (1996:335) state hope, Parker's (1998:839) self-efficacy, being the basis of Luthans' original scale, were used.

Additionally, a nominal scale is also used to measure 4 demographic questions and 13 queries about job tenure including total job tenure and the last job tenure, and also about the performance evaluation system. 
The variables that were tested in the model and their literature sources are shown in Table 1.

Table 1: The variables used in this study and their sources.

\begin{tabular}{|l|l|}
\hline Construct & Reference in the literature \\
\hline Positive Feedback & Sujan, Weitz and Kumar (1994) \\
\hline Negative Feedback & Sujan, Weitz and Kumar (1994) \\
\hline PsyCap & $\begin{array}{l}\text { Çetin and Basım (2012) adopted measure from Luthans, Youssef and Avolio (2007) that was } \\
\text { based on the scales of Scheiner and Carver's (1985) optimism, Wagnild and Young's (1993) } \\
\text { resilience, Snyder's et al. (1996) state hope (1996), Parker's (1998) self-efficacy. }\end{array}$ \\
\hline Demographic Variables & Luthans, Youssef and Avolio (2007), Parker (1998). \\
\hline
\end{tabular}

\section{Demographic and Job Characteristics of the Sample}

Women made up $44.3 \%$ of married people did $51.8 \%$ of the total sample. Almost half of the respondents (51.1.\%) were between 24 and 35 years old, $29.3 \%$ were between 36 and 45 years old, $8.8 \%$ were 23 years old or younger, and the rest were more than 46 years old. About education, $7.2 \%$ of the participants had completed high school, $10.1 \%$ of the sample are from vocational schools, $70.7 \%$ of them had attended university, and $11 \%$ had done graduate studies. As for posts, $43 \%$ of the participants held administrative posts, $51 \%$ were salaried employees, and $6 \%$ were salaried workers.

In terms of the job tenure, half of the respondents (52\%) had been in business life for more than 9 years, $30 \%$ of the attendants had been working for five years or less and the rest had been in professional life for longer than five and up to 9 years.

Regarding the current employment period, half of the respondents (51\%) had three years or less, $16 \%$ had been in that company between 3-5 years, $9 \%$ had been in the current place between 5-7 years and the rest had the current job for longer than seven years $(24 \%)$.

In respect of the last position duration, $48 \%$ of the attendants had been their last position for the last three years or less. $17 \%$ had their current post for between 3-5 years old, 19\% had for between 5-9 years and 16 $\%$ had kept their last post for longer than 9 years.

\section{FINDINGS AND ANALYSES}

\section{Factor and Exploratory Factor Analyses}

First, factor analysis was conducted with the constructs of positive feedback and negative feedback and of four dimensions of PsyCap that are hope, optimism, self-efficacy, and resilience to reduce the number of variables. Subsequently, we separately conducted EFA for the independent variables (positive and negative feedback) and the dependent variables (four dimensions of PsyCap). We used IBM-SPSS v21 to conduct the factor and the exploratory factor analysis. 
Journal of Global Strategic Management | V. 15 | N. 2 | 2021-December| isma.info | 089-106 | DOI: 10.20460/JGSM.2022.305

Table 2: Exploratory factor analysis (positive and negative feedback)

\begin{tabular}{|c|c|c|c|c|c|}
\hline Dimension & Codes & Statement & $\begin{array}{c}\text { Factor } \\
\text { Loading } \\
(\%)\end{array}$ & $\begin{array}{c}\text { Factor } \\
\text { Variance } \\
\text { Explained } \\
(\%)\end{array}$ & $\begin{array}{c}\text { Cronbach's } \\
\text { Alpha }\end{array}$ \\
\hline \multicolumn{6}{|c|}{ FEEDBACK } \\
\hline \multirow{7}{*}{$\begin{array}{l}\text { Positive } \\
\text { Feedback }\end{array}$} & FB1 & $\begin{array}{l}\text { When my supervisor thinks my performance is good, he or } \\
\text { she provides me with positive feedback }\end{array}$ & 0.882 & \multirow{7}{*}{37.517} & \multirow{7}{*}{0.942} \\
\hline & FB2 & $\begin{array}{l}\text { My supervisor commends me when he or she thinks I am } \\
\text { using the "right" techniques. }\end{array}$ & 0.866 & & \\
\hline & FB10 & $\begin{array}{l}\text { My supervisor lets me know when he or she thinks I am } \\
\text { producing good results. }\end{array}$ & 0.851 & & \\
\hline & FB3 & $\begin{array}{l}\text { My supervisor makes it a point of telling me when he or she } \\
\text { thinks I manage my time well. }\end{array}$ & 0.825 & & \\
\hline & FB5 & $\begin{array}{l}\text { When my supervisor is satisfied with my job output, he or she } \\
\text { comments about it. }\end{array}$ & 0.820 & & \\
\hline & FB7 & $\begin{array}{l}\text { My supervisor tells me when I deal with customers } \\
\text { appropriately. }\end{array}$ & 0.782 & & \\
\hline & FB8 & $\begin{array}{l}\text { My supervisor expresses his or her approval when he sees me } \\
\text { going about my job as he or she expects. }\end{array}$ & 0.781 & & \\
\hline \multirow{7}{*}{$\begin{array}{l}\text { Negative } \\
\text { Feedback }\end{array}$} & FB22 & $\begin{array}{l}\text { When my supervisor doesn't find me working the way he or } \\
\text { she expects, he or she lets me know. }\end{array}$ & 0.788 & \multirow{7}{*}{30.015} & \multirow{7}{*}{0.885} \\
\hline & FB19 & $\begin{array}{l}\text { When I fail to meet his or her sales expectations, my } \\
\text { supervisor indicates his or her dissatisfaction. }\end{array}$ & 0.767 & & \\
\hline & FB21 & $\begin{array}{l}\text { My supervisor would let me know if I did not demonstrate a } \\
\text { new product/service properly. }\end{array}$ & 0.767 & & \\
\hline & FB12 & $\begin{array}{l}\text { My supervisor lets me know when he or she is unhappy with } \\
\text { my performance results. }\end{array}$ & 0.757 & & \\
\hline & FB13 & $\begin{array}{l}\text { When my supervisor thinks I have veri something wrong, he } \\
\text { or she lets me know about it. }\end{array}$ & 0.731 & & \\
\hline & FB16 & $\begin{array}{l}\text { My supervisor is prompt in letting me know when my output } \\
\text { is below his or her expectations. }\end{array}$ & 0.714 & & \\
\hline & FB17 & $\begin{array}{l}\text { When I deal with customers in a way that my supervisor } \\
\text { disapproves, he or she lets me know. }\end{array}$ & 0.619 & & \\
\hline & \multicolumn{3}{|c|}{ TOTAL VARIANCE EXPLAINED } & 67.531 & \\
\hline & \multicolumn{3}{|c|}{ KMO-Kaiser-Meyer-Olkin Measure of Sampling Adequacy } & 0.929 & \\
\hline & \multicolumn{3}{|c|}{ Significance } & $\mathbf{0 . 0 0}$ & \\
\hline
\end{tabular}

As seen in Table 2, both positive and negative feedback variables kept seven statements instead of the original eight. An excellent KMO of 0.929 indicated the suitability of inter-dimension correlation in an adequate sample volume for conducting factor analysis with the significance of Bartlett's test of sphericity at 0.00 and total variance explained at \% 67.531. Both positive and negative dimensions were found to be reliable with Cronbach Alpha values exceeding 0.70 (Durmuş, Yurtkoru, and Çinko, 2010:89). 
Journal of Global Strategic Management | V. 15 | N. 2 | 2021-December| isma.info | 089-106 | DOI: 10.20460/JGSM.2022.305

Table 3: Exploratory factor analysis (dimensions of PsyCap)

\begin{tabular}{|c|c|c|c|c|c|}
\hline Dimension & Codes & Statement & $\begin{array}{r}\text { Factor } \\
\text { Loading } \\
(\%)\end{array}$ & $\begin{array}{c}\text { Factor } \\
\text { Variance } \\
\text { Explained } \\
(\%) \\
\end{array}$ & $\begin{array}{c}\text { Cronbach's } \\
\text { Alpha }\end{array}$ \\
\hline \multicolumn{6}{|c|}{ PSCHOLOGICAL CAPITAL(PsyCap) } \\
\hline \multirow{6}{*}{ SELF-EFFICACY } & PC19 & $\begin{array}{l}\text { I am confident in contacting people outside the company (e.g., } \\
\text { suppliers, customers) to discuss problems. }\end{array}$ & 0.803 & \multirow{6}{*}{30.462} & \multirow{6}{*}{0.868} \\
\hline & PC18 & $\begin{array}{l}\text { I am confident in contributing to discussions about the } \\
\text { company's strategy. }\end{array}$ & 0.787 & & \\
\hline & PC14 & I am confident in helping to set targets/goals in my work area. & 0.732 & & \\
\hline & PC16 & $\begin{array}{l}\text { I am confident in analyzing a long-term problem to find a } \\
\text { solution. }\end{array}$ & 0.719 & & \\
\hline & PC17 & $\begin{array}{l}\text { I am confident in representing my work area in meetings with } \\
\text { senior management. }\end{array}$ & 0.711 & & \\
\hline & PC15 & $\begin{array}{l}\text { I am confident in presenting information to a group of } \\
\text { colleagues. }\end{array}$ & 0.685 & & \\
\hline \multirow{4}{*}{ HOPE } & PC3 & $\begin{array}{l}\text { at present, I am closely pursuing my business goals to meet } \\
\text { them. }\end{array}$ & 0.813 & \multirow{4}{*}{20.049} & \multirow{4}{*}{0.787} \\
\hline & $\mathrm{PC} 1$ & $\begin{array}{l}\text { At this time, I am meeting the business goals that I have set for } \\
\text { myself. }\end{array}$ & 0.804 & & \\
\hline & PC2 & Right now, I see myself as being successful in my job. & 0.666 & & \\
\hline & PC4 & I can think of many ways to reach my business goals. & 0.590 & & \\
\hline \multirow{2}{*}{ OPTIMISM } & PC6 & I am a believer in the idea that "every cloud has a silver lining". & 0.861 & \multirow{2}{*}{14.490} & \multirow{2}{*}{0.734} \\
\hline & PC8 & I always look on the bright side of things in my job. & 0.845 & & \\
\hline & \multicolumn{3}{|c|}{ TOTAL VARIANCE EXPLAINED } & 65.000 & \\
\hline & \multicolumn{3}{|c|}{ KMO-Kaiser-Meyer-Olkin Measure of Sampling Adequacy } & $\mathbf{0 . 8 8 3}$ & \\
\hline & \multicolumn{3}{|c|}{ Significance } & 0.00 & \\
\hline
\end{tabular}

As shown in Table 3, PsyCap has three dimensions, different from the original four. Resilience did not appear in this research. Self-efficacy has kept the original 6 statements, hope is composed by 4 instead of the original 5, and optimism includes two statements whereas the original has 4 , displaying reliable compositions with Cronbach Alpha values exceeding 0.70. Three components explain 65 percent of total variance with a good $\mathrm{KMO}$ value of 0.883 indicating the suitability of inter-dimension correlation in an adequate sample size.

The resilience dimension of PsyCap contributed to the research with its original four statements but as a result of the factor analysis, three statements were eliminated because of their factor loadings below 0.5 and the fourth statement was eliminated during the test of reliability statistic, with a Cronbach alpha value of 0.422 , below the threshold value of 0.6 . In a conclusion, none of the four items of resilience was passed the tests. 


\section{Test of the research model}

Figure 1: The effect of feedback on three facets of the PsyCap (self-efficacy, hope, and optimism).

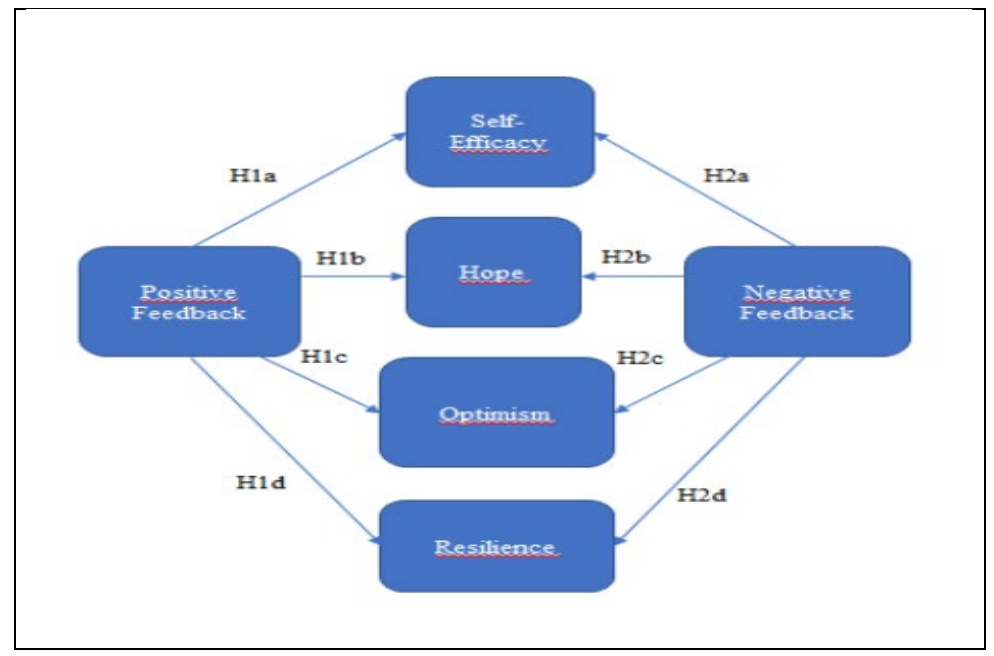

Confirmatory factor analyses (CFAs) were conducted to test the relationships between the variables of the model in Figure 1, as is presented in Table 4, including the fit indices values.

Table 4: CFA results of the model

\begin{tabular}{|c|c|c|}
\hline Dimensions & Codes of questions & Standardized Regression Coefficients \\
\hline \multirow{7}{*}{ Positive Feedback } & FB1 & 0.923 \\
\hline & FB2 & 0.890 \\
\hline & FB5 & 0.870 \\
\hline & FB10 & 0.831 \\
\hline & FB3 & 0.801 \\
\hline & FB7 & 0.768 \\
\hline & FB8 & 0.733 \\
\hline \multirow[t]{7}{*}{ Negative Feedback } & FB16 & 0.804 \\
\hline & FB13 & 0.765 \\
\hline & FB12 & 0.762 \\
\hline & FB21 & 0.720 \\
\hline & FB22 & 0.697 \\
\hline & FB19 & 0.616 \\
\hline & FB17 & 0.601 \\
\hline \multirow{6}{*}{ Self-Efficacy } & PC18 & 0.800 \\
\hline & PC19 & 0.723 \\
\hline & PC14 & 0.712 \\
\hline & PC17 & 0.684 \\
\hline & PC16 & 0.667 \\
\hline & $\mathrm{PC} 15$ & 0.640 \\
\hline \multirow[t]{4}{*}{ Hope } & PC3 & 0.791 \\
\hline & PC1 & 0.707 \\
\hline & PC4 & 0.688 \\
\hline & $\mathrm{PC} 2$ & 0.634 \\
\hline \multirow[t]{2}{*}{ Optimism } & PC8 & 0.776 \\
\hline & PC6 & 0.752 \\
\hline Model Fit Indices & Actual Values & Reference Values \\
\hline CMIN/DF & 2.5435 & \\
\hline GFI & 0.850 & \\
\hline CFI & 0.904 & \\
\hline NFI & 0.849 & \\
\hline RMSEA & 0.071 & \\
\hline
\end{tabular}

CFA was carried out with positive and negative feedbacks as two exogenous variables and self-efficacy, hope, and optimism as three endogenous variables of the tested model. 
In terms of the model fit, the likelihood ratio chi-square test, CMIN/df ratio, of 2.545 that is less than 3 , explains the fitness of the actual model to the assumed one (Carmen and McIber, 1981). On the other hand, comparative fit index (CFI) of 0.904, is greater than 0.90 (Bentler, 1990) and RMSEA (Browne and Cudeck, 1993 ) values of 0.71 , being less than 0.80 are acceptable values for the model fit.

Jayaram, Kanna, and Tan (2004, cited in Civelek, 2017:16) mentioned that the minimum required sample volume of the tested sample should be ten times of the tested statements. In this study, the tested number is 42 categorized statements (with five points Likert-scale) hence the minimum required sample volume could not, unfortunately, be obtained, instead, 307 has been hardly received. Therefore, the goodness of fit (GFI) of 850 (Tanaka and Huba, 1985) and normed fit- NFI of 0.849 and Tucker-Lewis -TLI (Bentler and Bonnett, 1980 ) indices that are close to 0.90 , accepted as the good fitness of the model, regarding the sample size smaller than the ideal volume (Xia and Yang, 2019).

The correlation coefficients of the latent variables and the AVE and CR values are presented in Table 5.

Table 5: Correlation coefficients and AVE and CR values

\begin{tabular}{|c|c|c|c|c|c|}
\hline & $\begin{array}{c}\text { Positive } \\
\text { Feedback }\end{array}$ & $\begin{array}{l}\text { Negative } \\
\text { Feedback }\end{array}$ & Self-Efficacy & Hope & Optimism \\
\hline $\begin{array}{l}\text { Positive Feedback } \\
\text { Negative Feedback } \\
\text { Self-efficacy } \\
\text { Hope } \\
\text { Optimism }\end{array}$ & $\begin{array}{c}(0.833) * \\
0.786\end{array}$ & $(0.713) *$ & $(0.706)$ * & $(0.707)$ * & $(0.768) *$ \\
\hline $\begin{array}{l}\operatorname{AVE}^{* *} \\
\text { CR }^{* * *} \\
\text { Cronbach's Alpha }\end{array}$ & $\begin{array}{c}0.69 \\
0.94 \\
0.942\end{array}$ & $\begin{array}{c}0.51 \\
0.88 \\
0.885\end{array}$ & $\begin{array}{c}0.50 \\
0.86 \\
0.868\end{array}$ & $\begin{array}{c}0.50 \\
0.80 \\
0.787\end{array}$ & $\begin{array}{c}0.58 \\
0.74 \\
0.734\end{array}$ \\
\hline
\end{tabular}

All reliability ratios of the constructs (CR) of the model are equal and/or higher than the threshold ratio of 0.70 , and average variance extracted (AVE) values of all dimensions are above or equal threshold value of 0.50 , indicating a successful explanation of the latent variables by their observed variables (Sharif, 2013). AVE values equal and greater than 0.5 , and all constructs reliability values greater than AVE values, shows us the convergent validity, and the correlation coefficient below the root square of the AVE verifies discriminant validity as indicated in Table 5. Furthermore, the statistically significant fit indices obtained because of CFA also bring nomological and face validity. In other words, different constructs that had been chosen (indicating face validity) from the previous studies, were consistently explained (indicating nomological validity) in the model (Paswan 2009). In conclusion, all necessary checkpoints were verified to pass the path analysis.

\section{Path Analysis}

As a result of the path analysis, positive feedback has a negative relationship with self-efficacy whereas negative feedback has a positive relationship, and the critical ratio values of positive and negative feedback are above the threshold $t$ value of 1.96 at a $5 \%$ significance level., as indicated by the figures in Table 6 .

Table 6: Regression coefficients: Self-Efficacy is endogenous.

\begin{tabular}{|c|c|c|c|}
\hline Path to Self-Efficacy & Regression Coefficients & Critical Ratio & Significance Level \\
\hline Positive Feedback & $\mathbf{- 0 . 1 7 4}$ & $\mathbf{- 1 . 9 6 2}$ & $\mathbf{0 . 0 5 0}$ \\
\hline Negative Feedback & $\mathbf{0 . 3 0 2}$ & $\mathbf{3 . 1 3 8}$ & $\mathbf{0 . 0 0 2}$ \\
\hline
\end{tabular}

According to the significance levels in Table 6, it can be concluded that H1a and H2a are supported.

Receiving positive feedback affects self-efficacy in a slightly negative way. Maybe employees do not push themselves to stand out in their job due to their belief in being appreciated by their seniors. On the other hand, negative feedback's impact on self-efficacy is higher than positive feedback. Based upon the regression coefficient of 0.302 . Probably, employees who are not happy with negative feedback afford all their skills in their job, and try standing out, to be appreciated, next time, 
Table 7: Regression coefficients: Hope is endogenous.

\begin{tabular}{|c|c|c|c|}
\hline Path to Hope & Regression Coefficients & Critical Ratio & Significance Level \\
\hline Positive Feedback & - & - & - \\
\hline Negative Feedback & 0.167 & 2.356 & 0.018 \\
\hline
\end{tabular}

As seen in Table 7, there is no path between positive feedback and hope, hence H1b is not supported, positive feedback does not affect hope. Nevertheless, negative feedback positively influences hope, with an acceptable $t$ value of 2.356 , greater than the threshold of 1.96 at a $5 \%$ significance level. $\mathrm{H} 2 \mathrm{~b}$ is supported.

Table 8 Regression coefficients: Optimism is endogenous.

\begin{tabular}{|c|c|c|c|}
\hline Path to Optimism & Regression Coefficients & Critical Ratio & Significance Level \\
\hline Positive Feedback & 0.265 & 3.300 & 0.000 \\
\hline Negative Feedback & - & - & - \\
\hline
\end{tabular}

As shown in Table 7, there is no path between negative feedback and optimism, therefore $\mathrm{H} 2 \mathrm{c}$ is not supported, negative feedback does not impact optimism. Meanwhile, positive feedback has a positive impact on optimism related to the regression coefficient of 0.265 , with an acceptable $t$ value of 3.300 greater than the threshold of 1.96 at a $5 \%$ significance level. H1c is supported.

Since the facet of resilience did not appear in this investigation, there is no way to find out the effect of positive and negative feedback on resilience. Consequently, H1d and H2d could not be supported.

\section{The moderating effects of total seniority on feedback and three dimensions of PsyCap}

As the last step of this empirical study, the moderating effects of total seniority on feedback and three dimensions of PsyCap were tested separately. Before testing the effects of the moderator, the standardized values of all the variables, which are referred to as $Z$ variables in the models, and the interaction of the predictor(s) and moderator were calculated with the program SPSS v21, and the $\mathrm{Z}$ and interaction values were tested with AMOS v21. The standardized values were preferred to be used to detect possible outliers, high leverage points and highly influential points to succesfully test moderating effects(statistics.laerd.com).

Table 9: Total Seniority Moderate Positive and Negative Feedback on Self-Efficacy

\begin{tabular}{|l|c|c|}
\hline Path to Z Self- Efficacy & Regression Coefficients & Significance Level \\
\hline Z Positive Feedback & 0.135 & 0.016 \\
Z Total Seniority & 0.172 & 0.002 \\
Interaction of Positive & -0.126 & $\mathbf{0 . 0 2 4}$ \\
Feedback and Total Seniority & & 0.949 \\
\hline Z Negative Feedback & -0.004 & 0.001 \\
Z Total Seniority & 0.161 & $\mathbf{0 . 0 4 1}$ \\
Interaction of Negative & -0.115 & \\
Feedback and Total Seniority & & \\
\hline
\end{tabular}

The above table (table 9) demonstrates the significance level of the interaction between positive and negative feedbacks and total seniority. Positive feedback and total seniority separately impact self-efficacy, moreover, they influence self-efficacy, together. It means, total seniority moderates the effect of positive feedback on self-efficacy, in a negative way due to the negative regression coefficient of -0.115 . In conclusion, H3a is supported. On the other hand, although the composite power of negative feedback and total seniority on self-efficacy is relevant at a 5 percent significance level, the path to negative feedback is not statistically significant Therefore, H3b is not supported.

Table 10: Total Seniority Moderate Positive Feedback on Optimism

\begin{tabular}{|l|c|c|}
\hline Path to Z Optimism & Regression Coefficients & Significance Level \\
\hline Z Positive Feedback & 0.106 & 0.063 \\
Z Total Seniority & 0.098 & 0.086 \\
Interaction of Positive Feedback and Total & -0.031 & $\mathbf{0 . 5 8 0}$ \\
Seniority & & \\
\hline
\end{tabular}


The significance level of the interaction of positive feedback and total seniority is above 0.05 , therefore, total seniority does not moderate the impact of positive feedback on optimism.H3c is not supported.

Table 10: Total Seniority Moderate Negative Feedback on Optimism

\begin{tabular}{|l|c|c|}
\hline Path to Z Hope & Regression Coefficients & Significance Level \\
\hline Z Negative Feedback & 0.058 & 0.310 \\
Z Total Seniority & 0.067 & 0.238 \\
Interaction of Negative Feedback and & -0.137 & $\mathbf{0 . 0 1 6}$ \\
Total Seniority & & \\
\hline
\end{tabular}

As the last step, the moderating effect of total seniority on the relationship of positive feedback and hope was observed. Although the interacted coefficient is statistically significant at 5 percent, other paths are not statistically significant. Significance levels are above 0.05 therefore, H3d is not supported, total seniority does not moderate the effect of negative feedback on hope.

Figure2: Final Model

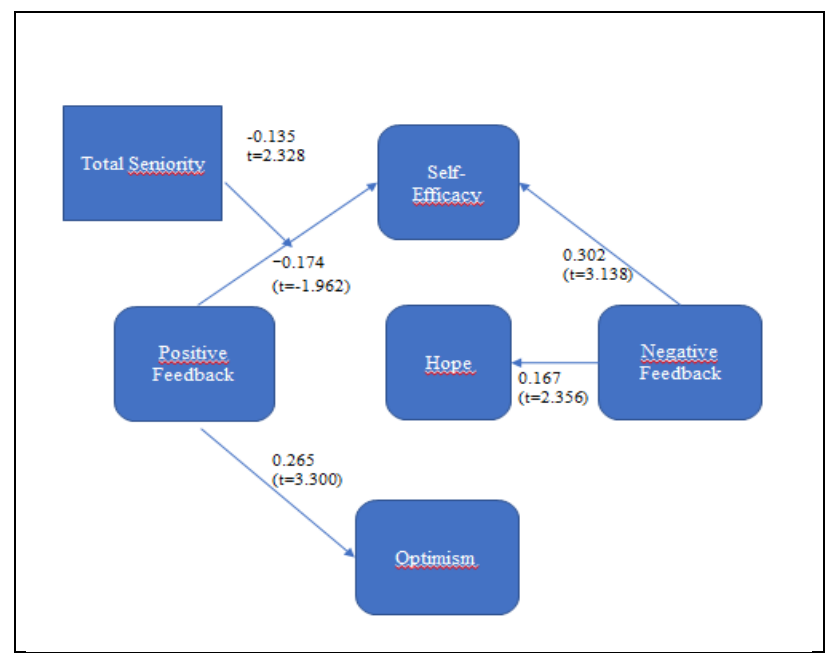

Figure 2 is the finalized model of this study which shows all relationships between the variables of the tested model at a 5\% significance level. As it is seen in the path analysis; both positive and negative feedbacks directly influence self-efficacy. On the other hand, positive feedback does not affect hope whereas negative feedback does. Again, positive feedback impacts optimism but negative feedback naturally does not. Moreover, among all the above available relationships, only positive feedback and selfefficacy are moderated by total seniority. It can therefore be concluded that the relationship between positive feedback and self-efficacy will be affected slightly in a negative direction in case of increasing total seniority. The total seniority effect would be positive to bring up self-efficacy due to the negative regression coefficient between positive feedback and self-efficacy, which would be turned positive direction while increasing seniority.

As we sum up the results of the hypotheses tests; H1a, H1c, H2a, H2b, H3a were supported whereas, H1b, H1d, H2c, H2d, H3b, H3c, H3d were not.

\section{DISCUSSION AND CONCLUSION}

At the beginning of the discussion part of this study, we looked from a broader framework, and we wanted to begin addressing a question: How much importance do organizations continue to give to internal customers while most of the work is left to robots in today's rapidly changing and developing technological world?" In the 1990s, Barney's resource-based approach stressed the importance of human resources for companies to provide a sustainable advantage. Competencies, capabilities, skills, or strategic assets are seen as a source of sustainable competitive advantage (Mabey et al., 1998) in the resource-based approach because of their valuable, rare, inimitable, and non-substitutable attributions (Barney, 1991). The employee must have the ability to evaluate his or her performance to be able to create a sense of competence. Perceptions about one's response capability are closely associated with a psychological state of the organism frequently described as a feeling of competence (Deci, 1975). Either the result of the task itself or the feedback of others provides the information needed to make a judgment about competence. Hackman and 
Oldham (1976) therefore emphasize that the greater the amount of feedback provided on a job, the greater will be the motivating potential of the job. Therefore, although rapid developments in technology have led us to different ways of working and forms of communication, we believe that the human resource of an organization is still the most important asset, and we assume that receiving positive and negative feedback is related to the psychological capital of internal customers.

In line with the hypothesis, the results of this research proved that either positive or negative feedback is related to different subdimensions of PsyCap. According to the results, both positive and negative feedback is statistically affecting self-efficacy. This is an expected result as it coincides with the literature. An individual's perception of having successfully performed own tasks is the most reliable predictor of selfefficacy (Britner and Pajares, 2006; Joet, Usher and Bressoux, 2011; Usher, 2009; Usher and Pajares, 2008). Social persuasion such as positive feedback and encouragement or negative feedback regarding one's capability from others (Chase, 1998; Zeldin and Pajares, 2000) can also affect self-efficacy appraisals (Usher and Pajares, 2008).

There is a long-standing precedent of using feedback that negatively evaluates another's performances, or attributes, terming it as failure feedback (Brockner, 1979; Svensson, 2015; Van-Dijk and Kluger, 2004). The feeling of failure, often linked with unpleasant emotions, low self-efficacy, and anxiety is coupled with a sense of hope and a recognition of the potential towards greater learning and goal progress. In other words, failure can be framed positively when feedback is interpreted as providing a path to improvement (Fong. et al, 2017). In line with the literature, the results of this study showed that positive feedback does not influence hope whereas negative feedback has a positive impact on hope.

Moreover, according to the results, a statistically positive impact of positive feedback on optimism, appeared. People with an optimistic outlook see setbacks as challenges and opportunities that can eventually lead to success (Luthans et al. 2005). So that the result of our study is consistent with previous studies. Optimism is related to positive feedback. Kuntz et al (2016) state resiliency as a behavioral capability, which reflects resource utilization and the ability to continually adapt at work (Kuntz et al., 2016). The results of this study showed that neither positive feedback nor negative feedback does not influence resilience. The emerging result can be explained as when an individual can cope with the negative consequences by him/herself maybe he/she may not need the thoughts and the guidance of others.

The aim of this study is not only to reveal the relationship between feedback and PsyCap's subdimensions but also to analyze the moderating effect of job tenure on these two variables. In this study, job tenure is evaluated as total tenure in work life span, total seniority. Human capital theory suggests that job tenure would be associated with greater job performance because employees gain more tacit knowledge about how to perform their jobs effectively over time (Schmidt, Hunter, \& Outerbridge, 1986). In line with the theory, in our study, we assume that the length of the tenure period can moderate the strength of the relationship between positive/ negative feedback and subdimensions of PsyCap. Consequently, it is revealed that the effect of positive feedback on self-efficacy is moderated by total seniority. Gist and Mitchell (1992), described self-efficacy as an individual's perception of personal task capability (which is not inherently an evaluative perception). To modify their behavior, people require not only knowledge and skills but also beliefs that they can change their behavior and improve themselves (Karoly, 1993; Kuhl, 1984; Markus and Nurius, 1986; Mischel, Cantor, and Feldman, 1996). In line with the previous studies, our study showed that the greater the total work experience would mean more possibility of receiving positive feedback which may tend to affect the beliefs and perceptions of personal task capability.

Personality traits have been widely recognized to have significant effects on various individual outcomes that are also suggested to be influenced by PsyCap (Barrick and Mount, 1991; Zimmerman, 2008). Moreover, the concept of leader-member exchange (sometimes labeled LMX) recognizes the fact that leaders do not have the same relationship with each of the followers, but they rather develop a specific relationship with each subordinate (Graen and Uhl-Bien, 1995). Social exchange theory predicts that these reciprocal relationships can predict many organizational outcomes. (Cropanzano and Mitchell, 2005). The assumption of these cases becomes a limitation in the research. Therefore, in future researches, personal traits and leader-member exchange can be analyzed concerning feedback and PsyCap. Furthermore, previous studies proved that PsyCap may have a positive effect on work attitudes and behaviors, Nevertheless, none of these outcomes is analyzed considering the effect of feedback. So that, in the future researches feedback may be analyzed as a moderating factor between PsyCap and job satisfaction, 
organizational commitment, absenteeism, turnover intention, organizational citizenship behavior (OCB), and work performance. Lastly, at the beginning of this research, we targetted to reach at least 440 employees but unfortunately, as a limitation, we were able to hardly reach only 307 employees from diffierent companies. Furthermore, another limitation is common methods variance which refers to the shared variance among measured variables that arises when they are assessed using a common method (Spector \& Brannick, 2009). In addition to this, the results might be affected by the sociability of respondents who want to provide positive answers.

Consequently, in an era of the growing concern of ambiguity of the rapid change in business life, where employees have trouble seeing what is next, either positive or negative feedback affects the psychological capital of employees. This research aims to add value to the literature by pointing out, a specific subject which is not been analyzed before, the relation between feedback and PsyCap. In addition to this, the results of this study add value also to the practice proving that giving feedback to the employees can affect their self-efficacy, hope, and optimism. 


\section{REFERENCES}

Abramson L.Y., Seligman M.E.P., and Teasdale J.D. (1978), "Learned Helplessness in Human: Critique and Reformulation", Journal of Abnormal Psychology, 87, pp.32-48.

Adams, V. H., Snyder, C. R., Rand, K. L., King, E. A., Sigmon, D. R., and Pulvers, K. M. (2002), “Hope in the Workplace", in Giacolone, R. and Jurkiewicz, C. (Eds.), Handbook of Workplace Spirituality and Organizational Performance, Sharp, New York, USA, pp. 367-377.

Ashford, S. J, and Tsui, A. S. (1991), "Self-Regulation for Managerial Effectiveness: The Role of Active Feedback Seeking”, Academy of Management Journal, 34, pp.251-280.

Ashford, S. J., Blatt, R., and VandeWalle, D. (2003), "Reflections on the Looking Glass: A Review of Research on Feedback-Seeking Behavior in Organizations", Journal of Management, 29, pp.773-799.

Bandura, A. (1986), Social Foundations of Thought and Action: A Social Cognitive Theory, PrenticeHall, Englewood Cliffs, NJ, USA.

Bandura, A., and Cervone, D. (1983), "Self-Evaluative and Self-efficacy Mechanisms Governing the Motivational Effects of Goal Systems", Journal of Personality and Social Psychology, 45, pp.1017-1028.

Barney, J.B. (1991), "Firms' Resources and Sustained Competitive Advantages”, Journal of Management, 17, pp.99-120.

Barrick, M.R.and Mount, M.K. (1991), "The Big Five Personality Dimensions and Job Performance: A Meta-Analysis”, Personnel Psychology, 44, pp. 1-26.

Bentler, P.M. (1990), “Comparative Fit Indexes in Structural Models”, Psychological Bulletin, 107, pp. 238-246.

Bentler, P.M. and Bonett, D.G. (1980), "Significance Tests and Goodness of Fit in the Analysis of Covariance Structures", Psychological Bulletin, 88, pp.588-606.

Brockner, J. (1988), Self-Esteem at Work: Research, Theory, and Practice. D.C. Heath \& Co, Lexington, Kentucky, USA.

Bowen, DE., and Schneider, B. (1988), "Services Marketing and Management: Implications for Organisational Behavior", in Stow, B. and Cummings LL, (eds), Research in Organisational Behavior, JAI Press, 10, Greenwich, CT, 10.

Britner, S. L., and Pajares, F. (2006), "Sources of Science Self-Efficacy Beliefs of Middle School Students", Journal of Research in Science Teaching,43, pp.485-499.

Brockner, J. (1979), “The Effects of Self-Esteem, Success-Failure, and Self-Consciousness on Task Performance", Journal of Personality and Social Psychology, 37, pp.1732-1741.

Carmines, E G and McIver, J. P. (1981), "Analysing Models with Unobserved Variables, in Bohrnstedt, G. W., and Borgatta, E, F. (eds), Social Measurement, Current Issues, Sage, London, pp. 65-115.

Chase, M. A. (1998), "Sources of Self-Efficacy in Physical Education and Sport", Journal of Teaching in Physical Education, 18, pp.76-89.

Civelek, M.E. (2018), The Methodology of Structural Equation Modelling, Beta Publications, Istanbul, Turkey.

Cropanzano, R. and Mitchell, M. S. (2005), "Social Exchange Theory: An Interdisciplinary Review", Journal of Management, 31(6), pp.874-900.

Curry, L. A., Snyder, C. R., Cook, D. I., Ruby, B. C., and Rehm, M. (1997), "The role of Hope in Student-Athlete Academic and Sports Achievement", Journal of Personality and Social Psychology, 73, pp.1257-1267.

Deci, E. L. (1975), Intrinsic Motivation, Plenum Press, New York, USA.

Demirbaş E. and Özek, H. (2020), "How Internal Customers' Job Tenure affects Four Dimensions of PsyCap", Journal of Yasar University, 15 (Special Issue), pp.316-328. 
Durmuş (Sipahi), B. and Yurtkoru, E.S. and Çinko, M. (2010), Data Analysis with SPSS in Social Sciences, 3rd.ed., Beta Publications, Istanbul, Turkey.

Erkuș, A., Fındıklı, M.A. (2013), "Psikolojik Sermayenin İș Tatmini, İș Performansı ve İșten Ayrılma Niyeti Üzerindeki Etkisine Yönelik Bir Araştırma”, İstanbul Üniversitesi İşletme Fakültesi Dergisi, 42 (2), pp.302-318.

Fong, C. J., Schallert, D.L., Williams, K. M., Williamson, Z. H., Warner, J. R., Lin, S., Kim, Y. W. (2018), "When Feedback Signals Failure but Offers Hope for Improvement: A Process Model of Constructive Criticism", Thinking Skills and Creativity, 30, pp.42-53.

George W. (1990), "Internal Marketing and Organisational Behavior: A Partnership in Developing Customer-Conscious Employees at Every Level”, Journal of Business Research, 20, pp.63 - 70.

Gist, M.E., and Mitchell, T.R. (1992), "Self-Efficacy: A Theoretical Analysis of Its Determinants and Malleability", Academy of Management Review, 17, pp.183-211.

Graen, G. B., and Uhl-Bien, M. (1995), "Relationship-Based Approach to Leadership: Development of Leader-Member Exchange (LMX) Theory of Leadership Over 25 Years: Applying a Multi-Level MultiDomain Perspective", The Leadership Quarterly, 6(2), pp. 219-247.

Gummesson E. (1987), “The New Marketing_-Developing Long-Term Interactive Relationships”, Long Range Plan, 20(4), pp.10- 20.

Hackman, J. R., and Oldham, G. R. (1975), “Development of the Job Diagnostic Survey”, Journal of Applied Psychology, 60, pp.159-170.

Herold, D.M. and Parsons, C.K (1985), “Assessing the Feedback Environment in Work Organizations: Development of the Job Feedback Survey”, Journal of Applied Psychology, 70(2), pp.290-305.

Hobfoll, S. E., Stevens N. R. and Zalta, A. K. (2015), "Expanding the Science of Resilience: Conserving Resources in the Aid of Adaptation, Psychological Inquiry", An International Journal for the Advancement of Psychological Theory, 26 (2), pp.174-180.

Hunter, L.W., and Sherry. M. B. T. (2007), "Feeling the Heat: Effects of Stress, Commitment, and Job Experience on Job Performance", Academy of Management Journal, 50(4), pp. 953-968.

Ilgen, D. R., Fisher, C. D., and Taylor, S. M. (1979), "Consequences of Individual Feedback on Behavior in Organizations”, Journal of Applied Psychology, 64, pp.349-371.

Jayaram, J., Kannan, V., and Tan, K.C. (2004), Influence of Initiators on Supply Chain Value Creation, in Civelek, M.E. (2017), The Methodology of Structural Equation Modelling, Beta Publications, İstanbul, p.16.

Joet, G., Usher, E. L., and Bressoux, P. (2011), "Sources of Self-Efficacy: An Investigation of Elementary School Students in France", Journal of Educational Psychology, 103, pp.649-663.

Karoly, P. (1993), "Mechanisms of Self-Regulation: A systems view”, Annual Review of Psychology, 44, pp.23-52.

Kluger, A.N., and DeNisi, A. (1996), "The Effects of Feedback Interventions on Performance: A Historical Review, a Meta-Analysis, and a Preliminary Feedback Intervention Theory", Psychological Bulletin, 119, pp. 254-284.

Kuhl, J. (1984), "Volitional Aspects of Achievement Motivation and Learned Helplessness: Toward a Comprehensive Theory of Action Control", in Maher, B.A. (Ed.), Progress in Experimental Personality Research, Academic Press, 13, New York, USA. pp. 99-171.

Kuntz, J., Naswall, K. and Malinen, S. (2016), "Resilient Employees in Resilient Organisations: Flourishing Beyond Adversity”, Industrial and Organisational Psychology, 9(2), pp.456-462.

Larson, J.R. (1989), “The Dynamic Interplay Between Employees' Feedback-Seeking Strategies and Supervisors' Delivery of Performance Feedback", Academy of Management Review, 14, pp. 408-422. 
Locke, E.A., and Latham, G.P. (2002), "Building a Practically Useful Theory of Goal Setting and Task Motivation", American Psychologist, 57, pp.705-717.

Luthans, F., Youssef, C. and Avolio, B. (2007), Psychological Capital: Investing and Developing Positive Organizational Behavior, Oxford University Press, New York, NY, USA.

Luthans, F., Avolio, B. J., Walumbwa, F. O., and Li, W. (2005), "The Psychological Capital of Chinese Workers: Exploring the Relationship with Performance", Management and Organization Review, 1, pp.247-269.

Luthans, F., Van Wyk, R., and Walumbwa, F. O. (2004), "Recognition and Development of Hope for South African Organizational Leaders", Leadership and Organization Development Journal, 25, pp. 512527.

Luthans, F. (2002a), "The Need for, and Meaning of Positive Organizational Behavior", Journal of Organizational Behavior, 2, pp. 695-706.

Luthans, F., and Jensen, S. M. (2002), "Hope: A New Positive Strength for Human Resource Development", Human Resource Development Review, 1, pp.304-322.

Mabey, C., Salaman, G., and Storey, J. (1998), "Strategic Human Resource Management, Sage, London, England.

Malhotra, N. (2009). Marketing Research: An Applied Orientation, 6th. Ed. Pearson, New Jersey, USA.

Markus, H., and Nurius, P. (1986), “Possible selves”, American Psychologist, 41, pp.954-969.

Mischel, W., Cantor, N., and Feldman, S. (1996), The Nature of Willpower and Self-Control, in Higgins, E.T. and Kruglanski, A.W. (Eds.), Social Psychology: Handbook of Basic Principles, Guilford, New York, USA. pp. 329-360).

Mohrw-Jackson, I. (1991), "Broadening the market orientation: An Added Focus on İnternal Customers", Human Resource Management, 30(4), pp.455-467. 67

Moss, S. E., Valenzi, E. R., and Taggart, W. (2003), “Are You Hiding from Your Boss? The Development of a Taxonomy and Instrument to Assess the Feedback Management Behaviors of Good and Bad Performers", Journal of Management, 29, pp. 487-510.

Ng, Thomas W.H., and Feldman, D.C. (2010), “Organizational Tenure and Job Performance”, Journal of Management, 36(5), pp.1220-50.

Parker, S. (1998), "Enhancing Role Breadth Self-Efficacy: The Roles of Job Enrichment and Other Organizational Interventions”, Journal of Applied Psychology, 83(6), pp.835-852.

Paswan, A. (2009), Confirmatory Factor Analysis and Structural Equations Modeling: An Introduction. Cob.unt.edu/CFA-SEM. May. (Accessed December 3, 2021).

Pearce, J.L., and Porter, L.W. (1986), "Employee Responses to Formal Performance Appraisal Feedback", Journal of Applied Psychology, 71, pp.211-218.

Peterson, S. J., and Luthans, F. (2003). "The Positive Impact and Development of Hopeful Leaders", Leadership and Organization Development Journal, 24(1), pp. 26-31.

Phillips, J.M., Hollenbeck, J.R., and Ilgen, D.R. (1996), Prevalence and Prediction of Positive Discrepancy Creation: Examining a Discrepancy Between Two Self-Regulation Theories", Journal of Applied Psychology, 81, pp.498-511.

Scheier, M.F and Carver, C.S. (1985), "Optimism, Coping, and Health Assessment and Implications of Generalized Outcome Expectancies”, Health Psychology, 4(3), pp. 219-247.

Schmidt, E L., Hunter, J. E., and Outerbridge, A. N. (1986), “The Impact of Job Experience and Ability on Job Knowledge, Work Sample Performance, and Supervisory Ratings of Job Performance", Journal of Applied Psychology, 71, pp.432-439.

Sharif, S.P. (2013). Book Summary: Applied Multivariate Research: Design and Interpretation. http: // saeedsharif.com/tag/path-analysis/ August. (Accessed December 03, 2021). 
Seligman, M. E. (1998), Learned Optimism: How to Change Your Mind and Your Life, Pocket Books, NY, USA.

Snyder, C. R. (2000), Handbook of Hope, Academic Press, San Diego, CA, USA.

Snyder, C.R., Sympson, S.C., Ybasco, F.C., Borders, T.F., Babyak, M.A. and Higgins, R.L. (1996), "Development and Validation of the State Hope Scale", Journal of Personality and Social Psychology, 70(2), pp.321-335.

Snyder, C. R. (1995b), “Managing for High Hope”, Research and Development Innovator, 4(6), pp.6-7.

Snyder, C. R., Irving, L., and Anderson, J. (1991)., "Hope and Health: Measuring the Will and the Ways", in Snyder C. R., and D. R. Forsyth, D.R. (Eds.), Handbook of Social and Clinical Psychology, Pergamon, Elmsford, NY, USA, pp.285-305.

Spector, P. E., and Brannick, M. T. (2009), "Common Method Variance or Measurement Bias? The Problem and

Possible Solutions". In D. Buchanan \& A. Bryman (Eds.), Handbook of Organizational Research Methods, Sage, London, UK., pp.346-362.

Statistics.laerd.com/spss-tutorials/dichotomous-moderator-analysis-using-spssstatistics (Accessed: December, 28, 2021).

Sujan, H., Weitz, B.A. and Kumar, N. (1994), "Learning Orientation, Working Smart, and Effective Selling”, Journal of Marketing, 58(July), pp.39-52.

Svensson, N. (2015), "Subjective Experiences of Creative Work After Negative Feedback", Thinking Skills and Creativity, 15, pp.26-36.

Tanaka, J.S. and Huba, G.J. (2011), “A Fit Index for Covariance Structure Models under Arbitrary GLS Estimation”, British Journal of Mathematical and Statistical Psychology, 38(2), pp.197-201.

Thorndike, E. L. (1913), Educational Psychology, Volume I: The Original Nature of Man. Columbia University, Teachers College, New York, USA.

Trope, Y., and Neter, E. (1994), "Reconciling Competing Motives in Self Evaluation: The Role of SelfControl in Feedback Seeking", Journal of Personality and Social Psychology, 66, pp.646-657.

Usher, E. L., and Pajares, F. (2008), "Sources of Self-Efficacy in School: Critical Review of the Literature and Future Directions", Review of Educational Research, 78, pp.751-796.

Usher, E. L. (2009), “Sources of Middle School Students' Self-Efficacy in Mathematics: A Qualitative Investigation”, American Educational Research Journal, 46, pp.275-314.

Van-Dijk, D., and Kluger, A. N. (2004), "Feedback Sign Effect on Motivation: Is it Moderated by Regulatory Focus?”, Applied Psychology: International Review, 53, pp.113-135.

Wagnild, G.M. and Young, H.M. (1993), "Development and Psychometric Evaluation of the Resilience Scale”, Journal of Nursing Management, 1(2), pp.165-178.

Weiss, H., and Sherman, J. (1973), "Internal-External Control as a Predictor of Task Effort and Satisfaction after Failure”, Journal of Applied Psychology, 57, pp.132-136.

Youssef, C. M., and Luthans, F. (2007), "Positive Organizational Behavior in the Workplace", Journal of Management, 33(5), pp.774-800.

Youssef, C. M., and Luthans, F. (2006), Positivity in the Middle East: Developing Hopeful Egyptian Organizational Leaders, in Mobley, W. and Weldon, E. (Eds.), Advances in Global Leadership, 4, Oxford, England, pp.283-297.

Xia, Y. and Yang, Y. (2019), "RMSEA, CFI, and TLI in Structural equation Modeling with Ordered Categorical Data: The Story They Tell Depends on the Estimation Methods", Behavior Research Methods, 51, pp.409-428 
Journal of Global Strategic Management | V. 15 | N. 2 | 2021-December| isma.info | 089-106 | DOI: 10.20460/JGSM.2022.305

Zeldin, A. L., and Pajares, F. (2000), “Against the Odds: Self-Efficacy Beliefs of Women in Mathematical, Scientific, and Technological Careers”, American Educational Research Journal, 37, pp.215-246.

Zimmerman, R.D. (2008), “Understanding the Impact of Personality Traits on Individuals' Turnover Decisions: A Meta-Analytic Path Model”, Personnel Psychology, 61, pp. 309-348. 